\title{
An Evaluation of Life Satisfaction within the Migratory Experience According to Psychosocial Variables
}

\author{
Macarena Vallejo Martín, Maria del Pilar Moreno-Jiménez \\ Málaga University, Málaga, Spain \\ Email: mpilar@uma.es
}

Received September $30^{\text {th }}, 2012$; revised October $31^{\text {st }}, 2012$; accepted November $26^{\text {th }}, 2012$

\begin{abstract}
This study attempts to discover which psychosocial variables effect whether a displaced person evaluates their migratory experience and their life in the new context as positive. The psychosocial variables studied are: social support, individual self-esteem, social identity, analysis of endogroup and exogroup, assimilation of host culture, and perception of the assessment of the host culture and level of retention of the original culture. The general objective is to discover to what degree these variables predict the level of life satisfaction in the new city of residence. Following an analysis of the data, we find that social support predicts satisfaction in $23.3 \%$. Furthermore, in order to generalise these findings across the overall immigrant population, resident in Spain, a comparison of three Spanish cities is carried out: Barcelona, Madrid and Málaga. The results show that although an identical pattern cannot be applied to all three cities, but in conclusion we can say that the variables with greater success in predicting life satisfaction are: social support, assimilation and assessment of host culture and self-esteem. (1)
\end{abstract}

Keywords: Immigration; Life Satisfaction; Assimilation of Host Culture; Social Support; Retention of Original Culture

\section{Introduction}

The migration experience is experienced by the person affected, in all its dimensions: mental-conceptual, affective-emotional, behavioural, relational, identity, etc. All of these have to be understood in the pursuit of well-being, freedom and integration (Melero \& Díe, 2010). Social intervention should have an impact on each of the different dimensions in order to achieve the overall well-being of the migrant. For this to work, it is essential to prevent risk factors and strengthen psychosocial protection factors which facilitate a positive assessment of the migratory experience and perception of satisfaction with the new life project.

In contrast to the general perception of the native population, migrants have particularly resilient modes of being and dealing with life especially in the face of difficulties and moments of change and a special strength and flexibility to deal with adverse conditions (Scott \& Scott, 1989). (2) However, the capacity of adaptation and all that the process of acculturation implies has a huge impact on a displaced person in every aspect of their life (Martínez, García, \& Martínez, 2004). (2) It is not so strange therefore that most studies on migration in the field of psychology have concentrated on analysing those factors most relevant to the process of adaptation, principally those which play a greater role in acculturative stress, and feelings of dis- placement or migratory grief (Moreno \& Vallejo, 2008; Tizón, Salamero, Sanjosé, Pellejero, Achotegui, \& Sainz, 1993). (2) Is it therefore possible to understand these factors as potentials to be developed for a better understanding of the migratory experience?

\section{Social Support}

Among the many factors studied that lead to a positive eva- luation of their migratory experience by the person who emigrates, can be found social support. This is because restructuring the fabric of interpersonal relationships takes on particular relevance as a source of psychosocial resources, essential for facing the demands associated with the migratory experience (Aroian, 1992; Lynam, 1985; Martínez, García, \& Maya, 1999). Having a network of support means it is possible to share problems, gain in opportunities for social participation and a sense of belonging etc. Different studies in our country (Martínez, 1996; Martínez, García, \& Maya, 2002; Lila, Gracia, Herrero, \& Robles, 2007; among others) have confirmed that a social support network is fundamental for the reinterpretation of the new culture, to establish new ties and to acquire new skills which enable the development of a new social strata rooted in a welcoming society furthering the successful outcome of the new life project. So, within the framework of the social networks available to a displaced person, the degree of contact maintained with the host culture is relevant as a way of approaching the same. These relationships can provide important information about the country in which they find themselves and can help to avoid feelings of segregation and marginalisation. It is not however always the case that these relationships have a positive effect on the immigrant's well-being. Some research has determined negative effects deriving from experiences of discrimination and ethnic prejudice (Halpern, 1993; Liebkind \& Jasinskaja-Lahti, 2000; Ryff, Keyes, \& Hughes, 2003). Therefore the positive or negative effect on well-being is at the heart of intergroup relationships between native populations and immigrates.

\section{Acculturative Strategy}

As Berry (1997) suggests in his Acculturation Model, an- 
other determining factor in whether a displaced person adopts to the new context is the acculturative strategy undertaken. This in turn is determined by two independent factors: retention of original culture and assimilation of host culture. Both the degree of retention of original culture and the assimilation of host culture are measured relative to the evaluation of the endogroup and the exogroup which the displaced person makes. The research carried out around Berry's model (1997) in different countries and with distinct ethnic groups shows that practically all groups choose the option of integration as the preferred strategy of acculturation (assimilation of the host culture whilst retaining their original culture) (Campani \& Catani, 1985; Neto, 1993; Oriol, 1985; Partridge, 1988; Sam, 1995), although some intergroup variations exist according to the different psychosocial indicators (age, length of stay, motives and immigration conditions etc.).

\section{Perception Assessment and Self-Esteem}

In addition a negative perception assessment on the part of the host population can have a harmful effect on the well-being of immigrants (Hernández, Pozo, Alonso, \& Martos, 2005). Therefore in the acculturation process the value the subject places on their own group is vital as is the perception they have of how they are valued as a member of that group. This assessment and perception of assessment which correspond to the social side of self-image are closely linked with individual self-esteem and are absolutely essential to the levels of adjustment and satisfaction felt by an immigrant in their new context. This relationship between individual self-esteem and collective self-esteem has been stressed in different studies (Luhtanen \& Crocker, 1992; Sánchez, 1999).

So, the way in which the displaced group and the native group value each other will have repercussions for the acculturation strategy that each one displays. This assessment can be influenced by various factors, among which can be found: level of identification with the group, perceived competition between groups, perceived cultural enrichment, the rigidity of their own values, underlying conflicts or levels of contact between groups etc. (Piontkowski, Florack, Hoelker, \& Obdrzálek, 2000).

To sum up, in the acculturation process a multitude of variables, individual and group, come into play and all of them have to be taken into consideration when predicting the evaluation that a displaced person makes of their migratory experience. The objective of this study is to discover whether some psychosocial variables reported in the literature as being influential for a successful adaptation and adjustment in a new context are also relevant in terms of life satisfaction, positive evaluation of the migratory process and well-being. Focus research on the positive elements and meet the own evaluation and perception of the person, and therefore, flee the "culturalist" vision of the migratory experience, are the main points of this study innovation. (5) Moreover, with the idea of extending the results to different contexts, three cities of reference are used: Málaga, Madrid and Barcelona. This work is based on the hypothesis that all the variables considered in the study are important in predicting the level of life satisfaction in the migration experience (4)

\section{Method}

\section{Participants (6) and Procedure (8)}

The study is made up of a total of 285 migrants, of whom
$49.8 \%$ are men and $50.2 \%$ are women. These people come from a total of thirty-six different countries from the five continents. The principal geographic area is Latin America with a percentage of $59.7 \%$; followed by the area of Maghreb with $21.3 \%$ and Sub-Saharan Africa with $9.5 \%$.

With respect to personal circumstances, $52.6 \%$ state that they are single, $39.6 \%$ are married or live with their partner and $7.8 \%$ are separated. The average age of the participants is 32 years old. Particularly relevant is that more than half of the participants (54\%) state they are unemployed. At the same time $40 \%$ have university studies and $47 \%$ to secondary level. Only $1.8 \%$ has no studies at all.

The majority of the subjects give the main reasons for emigration as being economic and the search for new opportunities. As for the respondents' administrative circumstances, the percentages are more equal in the four possible responses: pending, temporary (according to contract or length of studies), final documentation or undocumented.

The data was gathered in three Spanish cities in different autonomous communities: Málaga (37.9\%), Madrid (31.6\%) and Barcelona (30.5\%).

The questionnaire was administered with a choice of three languages: Spanish, English and French. The participation of the respondents was anonymous and voluntary. To access participants, we visited different places such as call shops, associations and offices of renewal of cards of residence, etc. Therefore, participation in the study was random trying to respect a balance in sex and place of origin (7).

\section{Measurements (9)}

The following instruments were used to measure the different variables:

- SAI questionnaire-2005 version (Strategies of Acculturation in Immigrants) by Moreno and Vallejo (2005). Comprising a total of 35 items with a four point response scale, from 1 ("Strongly disagree") to 4 ("Strongly agree"). This scale measures assimilation of host culture and retention of original culture. An example of items for each one of the factors could be "I try to know all of the Spanish cultural norms" and "I look for people from my culture to interact with" The reliability analysis for each one of these factors demonstrate a Cronbach Alpha of 0.87 for assimilation of host culture and 0.90 for preservation of original culture.

- Rosenberg Scale of Self-esteem (1965). Comprising 10 items with a four point response from 1 (Strongly disagree") to 4 (Strongly agree"). This scale measures individual selfesteem or a person's self-evaluation. An example of this scale item is: "I sometimes think I'm no good for anything" (10) The scale has a Cronbach Alpha of 0.713.

- Adaptation of the Scale of Life Satisfaction by Diener, Emmons, Larson and Griffen (1985) for immigrants (Vallejo, 2009). The original scale of Life Satisfaction by Diener et al. (1985) adapted to immigrants has been used, finally comprising a total of 6 items with a five point response ranging from 1 ("Totally disagree") to 5 ("Totally agree"). As examples of items on this scale: "almost everything in my life in Spain responds to my aspirations" and "In Spain I have achieved things that were important to me". (10) The Cronbach Alpha for the adapted version is 0.816 .

- Scale of Perception of Social Support by Duke-Unc (1995). 
It is made up of eleven items with a five point response from 1 ("Never") to 5 ("Always"). The scale measures perceived social support. Examples of items of this scale are: "Receive visits from friends and family" and "Receipt for help when I'm sick" (10). The reliability analysis demonstrates a Cronbach Alpha of 0.888 .

- Scale of Social Identity (Vallejo, 2009). The level of social identity is measured by 3 items with a five point response from 1 ("Totally disagree") to 5 ("Totally agree"). These items refer to: importance of group of origin, identification with and ties to said group. An example of this scale item is: "I identify with my original group" (10). The reliability analysis has a Cronbach Alpha of 0.851 .

- Scale of Assessment of Host Culture and Assessment of Own Culture (Vallejo, 2009). It is made up of two subscales of four items in each with a response format of 1 to 5,1 being "Very bad" to 5 "Very good". The scale measures Assessment of Host Culture and Assessment of Own Culture based on four aspects: eating habits, social relationships, cultural customs and ways of communicating. Examples of the items for these factors are "I value how the Spanish interact" and "I value the culture and customs of my country". The Cronbach Alpha for Assessment of host culture is 0.872 and for Assessment of Own Culture, 0.837 .

- Scale of Perception of Assessment (Vallejo, 2009). It comprises two items with responses of 1 to 5,1 being "Very bad" and 5 being "Very good". This scale measures the subject's perception of how the Spanish value people from their country. An example of an item is "I think the Spanish value the people of my country". The reliability analysis demonstrates a Cronbach Alpha of 0.879 .

\section{Results}

1) Descriptives of the psychosocial variables. Differences according to city of residence.

The psychosocial variables under discussion in this study are: life satisfaction, assimilation of host culture, retention of own culture, self-esteem, social identity, social support, assessment of host culture, assessment of own culture and perception of assessment of the host society. The descriptives of each one of these variables are collected together in Table $\mathbf{1}$.

According to the results of the different psychosocial variables the respondents in the study show a pretty high level of assimilation of the host culture and an equally high level of retention of original culture. However they value their own culture more and show high levels in social identity. The respondents also have average levels in perception of assessment of the host society. Furthermore they show high levels of self-esteem and a medium/high level in life satisfaction and social support. Below, these same descriptives are collected together according to city of residence (Table 2).

As can be seen the only variables that produce significant differences according to city of residence are assessment of own culture and perception of assessment on the part of the host society. With the objective of discovering between which cities these differences are created, the post hoc Scheffé test is applied. Obtaining in this way that both for assessment of own culture and for the perception of assessment of the host society, the significant differences are found between Málaga and Madrid. In both cases, the highest levels were seen in Málaga city. It is consistent therefore that in the city where own culture is
Table 1.

Descriptives of the psychosocial variables.

\begin{tabular}{lcc}
\hline & Means & D.T \\
\hline Assimilation of host culture (1 - 4) & 3.21 & 0.489 \\
Retention of own culture $(1-4)$ & 3.17 & 0.533 \\
Self-esteem $(1-4)$ & 3.23 & 0.462 \\
Satisfaction $(1-5)$ & 3.31 & 0.850 \\
Social Identity $(1-5)$ & 3.83 & 1.042 \\
Social Support $(1-5)$ & 3.59 & 0.798 \\
Ass.Host Culture $(1-5)$ & 3.83 & 0.823 \\
Ass.Own culture (1 - 5) & 4.17 & 0.704 \\
Perception assessment $(1-5)$ & 3.39 & 1.058 \\
\hline
\end{tabular}

Table 2.

Descriptives of psychosocial variables and differences according to city of residence.

\begin{tabular}{|c|c|c|c|}
\hline & Madrid & Málaga & Barcelona \\
\hline $\begin{array}{l}\text { Assimilation of host culture } \\
(1-4)\end{array}$ & 3.25 & 3.23 & 3.15 \\
\hline Retention of own culture $(1-4)$ & 3.26 & 3.16 & 3.08 \\
\hline Self-esteem $(1-4)$ & 3.26 & 3.24 & 3.20 \\
\hline Life satisfaction $(1-5)$ & 3.24 & 3.39 & 3.30 \\
\hline Social identity (1 - 5) & 3.86 & 3.98 & 3.62 \\
\hline Social support (1 - 5) & 3.59 & 3.61 & 3.55 \\
\hline Ass. of Host Culture (1 - 5) & 3.76 & 3.94 & 3.76 \\
\hline Ass. of Own Culture $(1-5)^{*}$ & 4.06 & 4.32 & 4.09 \\
\hline $\begin{array}{l}\text { Assessment of Host Culture } \\
(1-5)^{*}\end{array}$ & 3.22 & 3.58 & 3.33 \\
\hline
\end{tabular}

Note: ${ }^{*} p<0.05$.

the most highly valued, the highest levels of perception of assessment on the part of the host city are to be found.

2) Relationships between the different psychosocial variables.

According to the results (see Table 3) the correlation coefficients between life satisfaction and the rest of the psychosocial variables studied, with the exception of retention of original culture, are all statistically significant. A higher level of correlation can be found between life satisfaction and social support (0.485), assessment of host culture (0.459), assimilation of host culture (0.437) and self-esteem (0.349). Other variables that also correlate, although to a lesser degree are: perception of assessment of host society (0.289), social identity (0.271) and assessment of own culture (0.203).

On the other hand, it is clear that the variable retention of original culture correlates with social identity $(0.563)$ and assessment of own culture (0.555). At the same time, the variable assimilation of host culture correlates with assessment of host culture (0.572), self-esteem (0.30) and social support (0.30). This last variable significantly correlates with all the psychosocial variables considered in this study. Finally it should be noted that the assessment of host culture and perception of assessment by them. In conclusion, it can be observed that many of the variables studied within the process of acculturation correlate with each other and in particular with life satisfaction. Taken within the context of displacement it correlates with all 
Table 3.

Correlation coefficient of the assessment of the migratory experience (life satisfaction) with other psychosocial variables.

\begin{tabular}{|c|c|c|c|c|c|c|c|c|}
\hline & Factor Here & $\begin{array}{l}\text { Factor } \\
\text { There }\end{array}$ & Self-Esteem & $\begin{array}{c}\text { Social } \\
\text { Identity }\end{array}$ & $\begin{array}{l}\text { Social } \\
\text { Support }\end{array}$ & $\begin{array}{l}\text { Assessment } \\
\text { Host Culture }\end{array}$ & $\begin{array}{l}\text { Assessment } \\
\text { Own Culture }\end{array}$ & $\begin{array}{l}\text { Perception } \\
\text { Assessment }\end{array}$ \\
\hline Satisfaction & $0.437\left(^{* *}\right)$ & 0.076 & $0.349\left(^{* *}\right)$ & $0.271\left(^{* *}\right)$ & $0.485\left(^{* *}\right)$ & $0.459\left(^{* *}\right)$ & $0.203\left(^{* *}\right)$ & $0.289\left(^{* *}\right)$ \\
\hline Factor Here & 1 & 0.088 & $0.330\left(^{* *}\right)$ & $0.170\left(^{* *}\right)$ & $0.330\left(^{* *}\right)$ & $0.572\left(^{* *}\right)$ & $0.155\left(^{* *}\right)$ & $0.263\left(^{* *}\right)$ \\
\hline Factor There & & 1 & 0.060 & $0.563\left(^{* *}\right)$ & $0.211\left(^{* *}\right)$ & 0.035 & $0.555\left(^{* *}\right)$ & -0.040 \\
\hline Self-Esteem & & & 1 & $0.269\left(^{* *}\right)$ & $0.240\left(^{* *}\right)$ & $0.149\left(^{*}\right)$ & $0.155\left(^{* *}\right)$ & 0.059 \\
\hline Social Identity & & & & 1 & $0.294\left(^{* *}\right)$ & $0.150\left(^{*}\right)$ & $0.518\left(^{* *}\right)$ & 0.009 \\
\hline Social Support & & & & & 1 & $0.406\left(^{* *}\right)$ & $0.354\left(^{* *}\right)$ & $0.242\left(^{* *}\right)$ \\
\hline $\begin{array}{l}\text { Assessment Host } \\
\text { Culture }\end{array}$ & & & & & & 1 & $0.316\left(^{* *}\right)$ & $0.462\left(^{* *}\right)$ \\
\hline $\begin{array}{l}\text { Assessment Own } \\
\text { Culture }\end{array}$ & & & & & & & 1 & $0.236\left(^{* *}\right)$ \\
\hline
\end{tabular}

Note: ${ }^{* *}$ The correlation is significant to a level 0.01 (bilateral); ${ }^{*}$ The correlation is significant to a level 0.05 (bilateral).

the factors with the exception of retention of own culture.

3) Variables predictive of life satisfaction in the migratory experience.

In order to know which factors predict life satisfaction in the process of acculturation of immigrants, and as a way that a displaced person has of assessing their life in the new context, a regression analysis is done according to the stepwise method. The results are shown in Table 4.

As can be seen, the main predictive factors of life satisfaction considered in the study are: social support, assimilation of host culture, self-esteem and assessment of host culture. These four factors explain $37.1 \%$ of life satisfaction in the acculturation process, with the emphasis on social support, as by itself it explains $23.3 \%$ of the assessment of the migratory experience in the new context.

However when the regression model for predicting life satisfaction according to city of residence is applied, it is discernible how the variance percentage indicated is different in each case. So, in the city of Málaga the variables social support, self-esteem, assessment of host culture, social identity and perception of assessment explain $42.6 \%$ of life satisfaction. Madrid, on the other hand, has three significant variables which would explain a greater self-evaluation in the new context in $48.3 \%$ : assimilation of host culture, social support and assessment of host culture. Lastly, for the city of Barcelona the variables assimilation of host culture, self-esteem and social support explain life satisfaction in $33.8 \%$. As shown in the following table, although for all three cities of residence, social support appears as one of the factors for predicting life satisfaction in the host country; in the cities with greater density of population (Madrid and Barcelona) the principal factor is assimilation of host culture (Table 5).

\section{Discussions and Conclusions}

The migratory experience can be understood as an organic process which implies important changes in the individual's surroundings (García, Martínez, Albar, \& Santolaya, 2002; Martínez, 1997). The person who emigrates from one country to another should incorporate themselves into a new context, in which they change their customs, values, rules, positions of power, language etc. This process has been studied using different models of acculturation with different group and psy-
Table 4.

Regression coefficients of life satisfaction.

\begin{tabular}{clc}
\hline Variables of model & & $\mathrm{R}^{2}$ \\
\hline Social support & $0.485^{* *}$ & 0.233 \\
Social support & $0.382^{* *}$ & 0.317 \\
Factor Here & $0.311^{* *}$ & \\
Social support & $0.356^{* *}$ & \\
Factor Here & $0.261^{* *}$ & 0.342 \\
Self-esteem & $0.178^{* *}$ & \\
Social support & $0.299^{* *}$ & \\
Factor Here & $0.145^{*}$ & 0.371 \\
Self-esteem & $0.196^{* *}$ & \\
Assessment of host culture & $0.225^{* *}$ & \\
\hline
\end{tabular}

chosocial variables determinant in assessing the migratory project of a person who has moved away, and in the end their well-being in the new context.

In the study, four different psychosocial variables have been taken into account, and have proven to be relevant in the adaptation process for the acculturation models, previously mentioned. According to the results, four of the principal factors that predict a more positive assessment of the migratory experience and provide a greater level of life satisfaction in the new context are: social support, the assimilation and assessment of the host culture, and self-esteem. In other words, among this group of factors that explain levels of life satisfaction of an immigrant, is the factor that the immigrant perceives that they can count on a social network of support contact with the society to which they move, value themselves and value positively the host society. This pattern, although not in the same way, can also be applied to those factors that predict life satisfaction according to city of residence; Málaga, Barcelona or Madrid. The common factor of all three cities is social support, as it is also the factor that is by far the greatest predictive of life satisfaction in the city with least inhabitants. Furthermore, the level of social support perceived, correlates with the rest of the variables considered: assimilation of host culture and retention of original culture, self-esteem, social identity, assessment of host culture and of own culture and perception of assessment. These 
Table 5.

Regression coefficients for life satisfaction according to the city of residence.

\begin{tabular}{|c|c|c|c|c|c|c|c|c|}
\hline Málaga & & & Madrid & & & Barcelona & & \\
\hline $\begin{array}{l}\text { Variables } \\
\text { in model }\end{array}$ & $\beta$ & $\mathrm{R}^{2}$ & $\begin{array}{l}\text { Variables } \\
\text { in model }\end{array}$ & $\beta$ & $\mathrm{R}^{2}$ & $\begin{array}{l}\text { Variables } \\
\text { in model }\end{array}$ & $\beta$ & $\mathrm{R}^{2}$ \\
\hline Social support & $0.495^{* *}$ & 0.238 & Assim. Host culture & $0.618^{* *}$ & 0.375 & Assim. Host culture & $0.448^{* *}$ & 0.191 \\
\hline Social support & $0.444^{* *}$ & 0.313 & Assim. Host culture & $0.493^{* *}$ & 0.457 & Assim. Host culture & $0.322^{*}$ & 0.268 \\
\hline Self-esteem & $0.288^{* *}$ & & Social support & $0.320^{* *}$ & & Self-esteem & $0.316^{*}$ & \\
\hline Social support & $0.364^{* *}$ & 0.369 & Assim. Host culture & $0.335^{*}$ & 0.483 & Assim. Host culture & $0.200^{*}$ & 0.338 \\
\hline $\begin{array}{l}\text { Self-esteem } \\
\text { A.C. Host }\end{array}$ & $\begin{array}{l}0.270^{* *} \\
0.262^{*}\end{array}$ & & $\begin{array}{l}\text { Social support } \\
\text { A.C.Host }\end{array}$ & $\begin{array}{l}0.273^{*} \\
0.255^{*}\end{array}$ & & $\begin{array}{l}\text { Self-esteem } \\
\text { Social support }\end{array}$ & $\begin{array}{l}0.305^{*} \\
0.303^{*}\end{array}$ & \\
\hline Social support & $0.302^{* *}$ & & & & & & & \\
\hline $\begin{array}{c}\text { Self-esteem } \\
\text { A.C Host }\end{array}$ & $\begin{array}{l}0.232^{*} \\
0.278^{* *}\end{array}$ & 0.395 & & & & & & \\
\hline Social Identity & $0.191^{* *}$ & & & & & & & \\
\hline Social support & $0.279^{* *}$ & & & & & & & \\
\hline Self-esteem & $0.243^{*}$ & & & & & & & \\
\hline A.C Host & $0.190^{*}$ & 0.426 & & & & & & \\
\hline Social Identity & $0.224^{*}$ & & & & & & & \\
\hline Perc. Assessment & $0.212^{*}$ & & & & & & & \\
\hline
\end{tabular}

results are in agreement with other distinct studies in our country (Martínez, 1996; Martínez, 1997; Martínez et al., 1999; 2002; Lila et al., 2007) who also confirm that a social support network is fundamental to reinterpret the new culture, establish new ties and acquire new skills that allow a development of a new social strata, rooted in a welcoming society, encouraging success with their life project within the new context. Moreover according to various studies social support occupies a central position as a determinant social factor in health and psychological well-being (Cobb, 1976; Cohen, Gottlieb, \& Underwood, 2000; Eckersley, Dixon \& Douglas, 2001; Gracia, 1997; Montero, 2003; Ramírez \& Cusmille, 1997). This means that if support resources are important mediators between stressful life events and health and well-being, in the case of immigrants this relationship takes on particular relevance (Aroian, 1992; Cohen \& Wills, 1985; Delgado \& Humm-Delgado, 1982; Golding \& Baezconde-Garbanati, 1990; Martínez, García, Maya, Rodríguez $\&$ Checa, 1996). From among the diverse mechanisms that have been proposed in an attempt to explain the beneficial effects of social support three stand out as having a greater implication during the migratory experience, a sense of belonging, the exchange of resources and information and the role of protector, buffer of social support (Hernández et al., 2005).

Another of the main conclusions that can be extracted from this study is that the assessment of the migratory experience does not correlate with retention of original culture. Namely, the act of retaining the culture of the country of origin in the new place of residence does not related to whether the person feels more satisfied in the new context. These results contradict the commonly held view expressed in the classic literature on models of acculturation, in which the strategy of integration (retention of original culture and assimilation of host culture) is the most positive, satisfactory and functional for the immigrant in this regard. Ward, Bochner and Furham, (2001) maintain that, certainly in the case of the first generation, that cultural assimilation is associated with fewer problems of adaptation to the host society and a better emotional state. Moreover as suggested by Basabe, Zoblina and Páez (2004) the bicultural option (retention of original culture and assimilation of host culture) is associated with a proper adjustment but requires a greater effort, that from the beginning it is important to learn about the new culture. In fact, in two of the three cities (with large populations) the main factor for life satisfaction is assimilation of the host society. For this reason, questions such as how to relate to the native population, speak the language, conform to the cultural norms of the host country all appear to favour life satisfaction in the place in question.

To conclude, we determine that those factors which have a bearing on the level of adaptation in the process of acculturation can also provide clues as to the self-evaluation as person makes about their migratory experience. However if we only wish to stress the positive aspects of the process of acculturation, we see some differences. These differences are principally derived from taking as the central focus, the displaced person and the perception that they have of their own migratory experience. Therefore, as Perkins, Palmer and García-Ramírez (2011), have stated that they reached the conclusion that power and contextual factors are crucial in the processes and problems that the three communities involved face, in the migratory process (migrants, from origin and destination) and as such any investigation on migrants should respond to the necessities of the community, be focused on action and positive social change. This debate aims to draw attention to the necessity of overcoming certain "culturalism" in research agendas and make way for studies on psychosocial issues such as psychological well-being, social integration or reducing discrimination and prejudice. Therefore, the conclusions drawn from this study will be relevant for more appropriate social intervention and successful community service. By knowing which factors are important for an immigrant to positively evaluate the migratory experience we can advance in this direction.

\section{REFERENCES}

Aroian, K. J. (1992). Sources of social support and conflict for Polish immigrants. Quali-tative Health Research, 2, 178-207. doi:10.1177/104973239200200205

Basabe, N., Zoblina, A., \& Paéz, D. Socio-cultural integration and psychological adaptation of immigrants in the Basque Country. Vitoria-Gasteiz: Servicio Central de Publicaciones del Gobierno Vasco.

Berry, J. W. (1997). Immigration, acculturation and adaptation. Applied Psychology: An International Review, 46, 5-61. 
Cobb, S. (1976). Social support as a moderator of life stress. Psychosomatic Medicine, 38, 300-314.

Cohen, S. Gottlieb, B. H., \& Underwood, L. G. (2000). Social relationships and health. In S. Cohen, L. G. Underwood, \& B. H. Gottlieb (Eds.), Social support measurement and intervention: A guide for health and social scientists (pp. 3-25). Oxford: Oxford University Press.

Cohen, S., \& Wills, T. A. (1985). Stress, social support and the buffering hypothesis. Psychological Bulletin, 98, 310-357. doi:10.1037/0033-2909.98.2.310

Campani, G., \& Catani, M. (1985). Associative networks in France and Italian youth. Revue Européenne des Migrations Internationales, 1, 143-160. doi:10.3406/remi.1985.986

Delgado, M., \& Humm-Delagado, D. (1982). Natural support systems: Source of strength in Hispanic communities. Social Work, 27, 83-89.

Diener, E., Emmons, R. A., Larsen, R. J., \& Griffin, S. (1985). The satisfaction with life scale. Journal of Personality Assessment, 49, 71-75. doi: $10.1207 /$ s 15327752jpa4901 13

Eckersley, R., Dixon, J., \& Douglas, B. (Eds.) (2001). The social origins of heath and well-being. Nueva York: Cambridge University Press.

García, M., Martínez, M. F., Albar, M. J., \& Santolaya, F. J. (2002). Immigrants and social natural resources. The application of the social convoy method in the acculturation process. Migraciones, 11, 83111.

Golding, M. J., \& Baezconde-Garbanati, L. A. (1990). Ethnicity, culture and social resources. American Journal of Community Psychology, 18, 359-370. doi:10.1007/BF00938118

Gracia, E. (1997). Social support in community intervention. Barcelona: Paidós.

Halpern, D. (1993). Minorities and mental Health. Social Sciences and Medicine, 36, 597-607. doi:10.1016/0277-9536(93)90056-A

Hernández, S., Pozo, C., Alonso, E., \& Martos, M. J. (2005). Structure and functions of social support in a group of moroccan immigrants. Anales de Psicología, 21, 304-315.

Liebkind, K., \& Jasinskaja-Lahti, I. (2000). The influence of experiences of discrimination on psychological stress: A comparison of seven immigrant groups. Journal of Community and Applied Social Psychology, 10, 1-16.

doi:10.1002/(SICI)1099-1298(200001/02)10:1<1::AID-CASP521>3. $0 . \mathrm{CO} ; 2-5$

Lila, M. Gracia, E., Herrero, J., \& Robles, M. (2007). Indicators of social intergration in latin american immigrants.Perspectives and retrospectives in Social Psychology at the outset of the XXI century. Madrid: Biblioteca Nueva.

Luhtanen, R., \& Crocker, J. (1992). A collective self esteem scale: Self evaluation of one's social identity. Personality and social Psychology Bulletin, 18, 302-318. doi:10.1177/0146167292183006

Lynam, M. J. (1985). Support networks developed by immigrant women. Social Science and Medicine, 21, 327-333. doi:10.1016/0277-9536(85)90109-1

Martínez, M. C. (1996). Psycosocial analysis of prejudice. Madrid: Síntesis.

Martínez, M. F. (1997). Stress and social support in the migratory process. In M. Hombrados (Ed.), Stress and health (pp. 297-318). Valencia: Promolibro.

Martínez, M. F., \& García, M. M. J. (2004). Immigration and intergroup conflict: A psycho-social attitudes and racist prejudices approximation. Inmigración, Sociedad y Estado: Una cuestión abierta. Sevilla: Junta de Andalucía.

Martínez, M. F., García, M., \& Maya, I. (1999). The role of natural social resources in the migratory process. Psycosocial Intervention, 8 ,
221-232.

Martínez, M. F., García, M., \& Maya, I. (2002). Social support and locus of control as predictors psychological well-being in Moroccan and Peruvian immigrant women in Spain. International Journal of Intercultural Relations, 26, 287-310. doi:10.1016/S0147-1767(02)00005-6

Martínez, M. F., García, M., Maya, I, Rodríguez, S., \& Checa, F. (1996). The social integration of African immigrants in Andalucia, needs and resources. Sevilla: Junta de Andalucía.

Melero, L., \& Díe, L. (2010). The psicosocial focus in migrations. In L. Melero (coord.), The person beyond migration: Manual of psycosocial intervention with migrants (pp. 71-114). Fundación CeiMigra.

Montero, M. (2003). Theory and Practice of community psychology: Tension between community and society. Barcelona: Paidós.

Moreno, M. P., \& Vallejo, M. (2005). Strategies of acculturation in immigrant populations. Results with questionnaire EAI-2005; Strategies of Acculturation in Immigrants. In J. M. Sabucedo, J. Romay, \& A. López-Cortón (Eds.), Psychological, political, cultural, immigration and social communication (pp. 123-130). Biblioteca Nueva.

Moreno, M. P., \& Vallejo, M. (2008). Immigration from a psychosocial perspective. Inmigración e Integración: Aspectos sociales y legales (pp. 39-54). Sequitur.

Neto, F. (1993). Some contributions to psychological research in understanding the Portuguese migratory phenomenon. In M. ReyVon Allmen (Ed.), Clinical psychology and cultural questions. París: L'Harmattan.

Oriol, M. (1985). Lorde identities. Revue Européenne des Migrations Internationales, 1, 171-184. doi:10.3406/remi.1985.988

Partridge, K. (1988). Acculturation attitudes and stress of Westerners living in Japan. In J. W. Berry, \& R. C. Annis (Eds.), Ethnic psychology (pp. 105-113). Amsterdam: Swets and Zeitlinger.

Perkins, D. D., Palmer, N. A., \& García-Ramírez, M. (2011). Psychological studies on migrations and community. Psychosocial Intervention, 20, 1-7.

Ramírez, V., \& Cumsille, P. (1997). Evaluating the efficiency of a community support program for adolescent motherhood. Revista Latinoamericana de Psicología, 29, 267-286.

Rosenberg, M. (1965). Self-image of the adolescent and society. Buenos Aires: Paidós.

Ryff, C. D., Keyes, C. L., \& Hughes, D. L. (2003). Status inequalities, perceived discrimination, and eudaimonic well-being: Do the challenges of minority life hone purpose and growth? Journal of Health and Social Behavior, 44, 275-291. doi:10.2307/1519779

Sam, D. L. (1995). Acculturation attitudes among young immigrants as a function of perceived parental attitudes to cultural change. Journal of Early Adolescence, 15, 238-258. doi: $10.1177 / 0272431695015002004$

Sánchez Santa-Bárbara, E. (1999). Relationship between personal self-esteem, collective self-esteem and participation in the community. Annals of Psychology, 15, 251-260.

Scott, W., \& Scott, R. (1989). Adaptation of immigrants: Individual differences and determinants. International Series in Experimental Social Psychology, 18. Oxford: Pergamon Press.

Tizón, J., Salamero, M., Sanjosé, J., Pellejero, N., Achotegui, J., \& Sainz, F. (1993) Migration and Mental health. Barcelona: PPU.

Vallejo M. (2009) Life satisfaction in the acculturation process in immigrants: Proposal of a model. Doctural Thesis unpublished, Málaga: University of Málaga.

Ward, C., Bochner, S., \& Furrham, A. (2001). The psychology of culture chock. East Sussex: Routledge. 